\title{
Trophic interactions between ciliates and nematodes from an intertidal flat
}

\author{
Ilse Hamels ${ }^{1, *}$, Tom Moens ${ }^{2}$, Koenraad Muylaert ${ }^{1}$, Wim Vyverman ${ }^{1}$ \\ ${ }^{1}$ Section of Protistology and Aquatic Ecology, and ${ }^{2}$ Marine Biology Laboratory, Department of Biology, University of Gent, \\ K.L. Ledeganckstraat 35, 9000 Gent, Belgium
}

\begin{abstract}
The present study investigated the possibility of a trophic link between ciliates and nematodes in fine sandy sediments of the Molenplaat intertidal flat (Schelde estuary, SW Netherlands). Grazing experiments were conducted under controlled laboratory conditions, with ciliate species isolated from enrichment cultures and nematodes collected directly from the field. Significant reductions in ciliate numbers were found in the presence of the predatory nematode Enoploides longispiculosus, a prominent species (and genus) in fine to medium sandy sediments of the North Sea and adjacent estuaries. No such effects were found when ciliates were inoculated with a mix of mainly deposit-feeding nematodes from the same sampling site. On the basis of these results, ciliate predation by E. longispiculosus was tested for several benthic ciliate species and abundances, at a range of predator abundances and temperatures, and in the presence of alternative prey (in casu nematodes). E. longispiculosus significantly reduced the densities of 5 out of 6 ciliate species offered as prey. Depending on the experimental conditions and the prey species, predation rates ranged from 0.19 to 10.8 ciliates predator ${ }^{-1} \mathrm{~h}^{-1}$, corresponding to a biomass consumption of 0.001 to $0.33 \mu \mathrm{g} C$ predator $^{-1} \mathrm{~d}^{-1}$. An overall positive relation between available ciliate biomass and predation rate was found. Comparison of experimental data with field conditions suggests that a considerable part of the ciliate production in fine sandy sediments of the Molenplaat is likely to be consumed by $E$. longispiculosus, which largely dominates meiofaunal biomass there. Estimated carbon requirements for the predator and production estimates of ciliate and nematode prey at the study site strongly suggest that ciliates are probably a far more important carbon source for E. longispiculosus than nematode prey, at least between late spring and autumn. This implies that carbon transfer from primary producers and bacteria to predatory nematodes may to a large extent be mediated through the microbial food web. In view of the generally high densities and biomasses of ciliates as well as predacious nematodes in fine sandy sediments, similar patterns are to be expected in many other estuarine and marine sediments.
\end{abstract}

KEY WORDS: Predation $\cdot$ Ciliates $\cdot$ Nematodes $\cdot$ Intertidal flat $\cdot$ Microbial food web $\cdot$ Grazing experiments Resale or republication not permitted without written consent of the publisher

\section{INTRODUCTION}

In pelagic ecosystems, the microbial food web has been found to form a loop to the classical algae-zooplankton-fish food chain (Azam et al. 1983, Sherr \& Sherr 1994). Bacteria growing on algal exudates are consumed by flagellates, which in turn are food for the microzooplankton, mainly ciliates and rotifers. Consumption of flagellates, ciliates and other microzoo-

*E-mail: ilse.hamels@rug.ac.be plankton by mesozooplankton (e.g., copepods and cladocerans) forms a link to the traditional food chain (e.g., Sanders \& Porter 1990, Stoecker \& Capuzzo 1990, Arndt 1993, Levinsen et al. 2000). In contrast to pelagic systems, this microbial food web concept has been much less studied in aquatic sediments. Benthic protozoa, especially flagellates and ciliates, are often highly abundant (e.g., Gasol 1993, Hamels et al. 1998, Dietrich \& Arndt 2000), and have been shown to consume various food sources, including bacteria, algae and dissolved organic matter (Fenchel 1968, Sanders 1991). 
Remarkably little is known, however, about links between benthic protozoa and higher trophic levels. Yet this sort of information is related to arguments about whether protozoa are sinks or links for carbon in benthic environments, and to the discussion about the relative strengths of top-down and bottom-up controls on heterotrophic protozoan biomass. One obvious reason why predation of flagellates and ciliates by metazoa has hitherto been largely ignored is that their soft bodies are seldom recognizable in the gut contents of potential consumers, while direct observations of trophic interactions in sediments are problematic.

Most previous experimental studies addressing interactions between benthic proto- and metazoa have used designs in which the effect of an increase or reduction in meio- or macrobenthic abundances on protozoan density or community composition was studied (Epstein \& Gallagher 1992, Walters \& Moriarty 1993, Bott \& Borchardt 1999, Wickham et al. 2000). The observed effects reflected positive as well as negative interactions, but the experimental designs did not allow confirmation of which (trophic) interactions caused the changes in protist density or community composition. Although one should be careful in extrapolating results from controlled laboratory experiments to the field situation, this type of study allows the evaluation of the role of single trophic interactions. Predation of ciliates by marine (epi)benthic harpacticoid copepods has been shown in laboratory experiments (Rieper \& Flotow 1981, Rieper 1985), with predation rates on ciliates of the genus Uronema amounting to a maximum of 192 ciliates copepod ${ }^{-1} \mathrm{~h}^{-1}$. These experiments were, however, performed in water, and it is unclear to what extent the observed rates can be translated to a benthic environment.

In marine sediments, ciliates typically have a maximum occurrence in fine sands (Fenchel 1969), and high ciliate abundances and biomasses have been found in several marine and estuarine fine sandy sediments with low silt content (Fenchel 1967, Al-Rasheid \& Sleigh 1995, Epstein 1997, Wickham et al. 2000). In the Schelde estuary (SW Netherlands), ciliate abundances ranging from $1.6 \times 10^{3}$ to $5.6 \times 10^{3} \mathrm{~cm}^{-2}$, corresponding to a biomass of 2.4 to $12.6 \mu \mathrm{g} \mathrm{C} \mathrm{cm}^{-2}$, were found in fine sandy sediments of an intertidal flat (Hamels et al. 1998, Hamels pers. obs.). In nearly all estuarine and marine sediments, nematodes are numerically the dominant metazoans. This also holds true for intertidal sediments of the Schelde estuary, where they costitute on average over $90 \%$ of total meiofaunal densities (Soetaert et al. 1994). Although both ciliates and nematodes are numerous in marine fine sandy sediments, and although some nematode species were shown to be capable of ingesting ciliates (von Thun 1968, Bouwman et al. 1984, Moens \& Vincx
1997, E. Olafsson pers. comm.), quantitative data concerning nematode predation on ciliates are lacking.

The present study addressed the following question: Can nematode predation on ciliates constitute a significant trophic link in fine sandy estuarine tidal flat sediments? That is, are nematodes capable of regulating ciliate biomass in intertidal sediments or may ciliates contribute significantly to the nematode diet? Feeding experiments were performed under controlled laboratory conditions, with ciliate cultures and nematodes originating from the Molenplaat, an intertidal flat in the Schelde estuary.

\section{MATERIALS AND METHODS}

Prey and predatory organisms. The organisms used in our experiments originated from the Molenplaat, an intertidal flat in the polyhaline reaches of the Schelde estuary (SW Netherlands). This tidal flat has been intensively studied in terms of ecological, biogeochemical and physical processes in the framework of the ECOFLAT (Eco-metabolism of an estuarine tidal flat) project. Major emphasis was on 2 study sites with contrasting sediment characteristics (see Middelburg et al. 2000 and Herman et al. 2000 for a description of these sites, S2 and S4). For our experiments, sediment was collected at a fine sandy site (S4 in the aforementioned studies), where ciliates are very abundant (Hamels et al. 1998). Ciliate species were cultured in the laboratory, whereas nematodes were collected from the field before each experiment.

Six ciliate species were used in our experiments (Table 1): the hypotrichs Aspidisca sp., Euplotes bisulcatus Kahl and Euplotes mutabilis Tuffrau, 2 scutico-

Table 1. Ciliate species used for the experiments: mean dimensions and biovolume. Mean dimensions and biomass of the predator Enoploides longispiculosus and the prey nematode species Monhystera sp.

\begin{tabular}{|c|c|c|c|}
\hline & $\begin{array}{l}\text { Length } \\
(\mu \mathrm{m})\end{array}$ & $\begin{array}{l}\text { Width } \\
(\mu \mathrm{m})\end{array}$ & $\begin{array}{c}\text { Biovolume/ } \\
\text { biomass }\end{array}$ \\
\hline Ciliates & & & $\left(\mu \mathrm{m}^{3}\right)$ \\
\hline Aspidisca sp. & 28 & 24 & 4000 \\
\hline Euplotes bisulcatus ${ }^{\mathrm{a}}$ & 40 & 23 & 7500 \\
\hline Euplotes mutabilis ${ }^{\mathrm{a}}$ & 98 & 64 & 85000 \\
\hline Cyclidium sp. 1 & 32 & 13 & 2700 \\
\hline Cyclidium sp. 2 & 19 & 12 & 1500 \\
\hline Chlamydodon triquetrus ${ }^{\mathrm{a}}$ & 108 & 47 & 80000 \\
\hline Nematodes & & & $\left(\mu \mathrm{g} \mathrm{C}\right.$ ind.$\left.^{-1}\right)$ \\
\hline Monhystera sp. & 1030 & 34.5 & 0.047 \\
\hline Enoploides longispiculosus & 2300 & 90 & 1.2 \\
\hline
\end{tabular}


ciliates from the genus Cyclidium (sp. 1 and 2) and Chlamydodon triquetrus (Müller) Dragesco from the order Cyrtophorida. Ciliates were isolated from Molenplaat sediments (after enrichment by the addition of rice grains or diatoms to sediment suspensions; Caron 1993) and grown monospecifically (unless stated otherwise) in Petri dishes containing filtered (Whatman GF/C) habitat water, adjusted to a salinity of 18 with Milli-Q water. Not all these ciliate species are very common on the Molenplaat; rather, they are the most easily cultivated species. C. triquetrus is a strictly herbivorous species (Fenchel 1968), which can be temporarily very abundant on the Molenplaat (up to $\sim 500$ cells ml$^{-1}$ ). The other species were cultured with bacteria as a food source, even though the Euplotes spp. are also capable of feeding on small diatom species (authors' pers. obs.). In contrast to Euplotes, the genera Cyclidium and Aspidisca are very common on the Molenplaat (up to $\sim 1100$ and 700 cells ml $^{-1}$, respectively). Cyclidium species swim freely in the interstitial water, while the other species are dorsoventrally flattened and usually creep along the surface of sediment particles. Stock cultures were stored at $10^{\circ} \mathrm{C}$ under a $12 \mathrm{~h}$ light:12 h dark cycle. Raw rice grains were added as a carbon source for bacteria in cultures of bacterivorous ciliates. Bacterial inocula were transferred with the ciliates. C. triquetrus was fed diatoms harvested from an Amphora cymbamphora culture (also originating from the Molenplaat) maintained in $\mathrm{f} / 2$-medium (Guillard, Sigma, Aldrich Corp., St. Louis, MO) prepared with sterile, filtered habitat water. Cultures were renewed weekly by transferring a few ciliates to fresh medium. To obtain enough cells for experiments, ciliates were grown in $250 \mathrm{ml}$ Erlenmeyer flasks at 10 to $22^{\circ} \mathrm{C}$ (depending on the species) with soy sauce as a carbon source (1 $\mathrm{ml} \mathrm{l}^{-1}$; Tso \& Taghon 1999) instead of rice grains. Cultures used for the experiments were 3 to $5 \mathrm{~d}$ old and at the end of logarithmic growth phase. Ciliate densities were determined from counts in Sedgwick-Rafter cells of glutaraldehyde-preserved ( $2 \%$ final concentration) subsamples. Ciliate densities were adjusted to the density desired for the experiment by appropriate dilution with filtered habitat water of the same salinity or by concentration by means of gentle centrifugation $(1500 \times g, 5 \mathrm{~min})$. Bacterial or diatom food was not removed. Ciliate cell volumes were estimated from measurements of living cells $(\mathrm{n}=25)$ (Table 1$)$. A prolate spheroid shape was assumed for Cyclidium species, whereas the volume of the other species was assumed to correspond to half the volume of an ellipsoid. Biovolumes were converted to organic carbon content using a conversion factor of

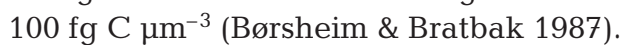

Samples for the extraction of predatory nematodes were collected by scraping off roughly the upper $2 \mathrm{~cm}$ of sediment. Sediment was stored at $4^{\circ} \mathrm{C}$ until the experiments, which took place within $3 \mathrm{~d}$ of sampling. Experiments were carried out at the end of May, September and October 1999, and at the end of August and the beginning of September 2000. Enoploides longispiculosus was always by far the most abundant nematode species at our sampling site. The genus Enoploides is - after some training - readily recognizable using a dissecting microscope at low magnification. It is characterized, among others, by its prominent mouth morphology, including 2 onchial plates and 3 bifurcate mandibles, and a strongly muscular pharynx, features illustrative of its predatory feeding mode. The species identification was based on the work of Platt \& Warwick (1983). Several tens of individuals were observed at high magnification on the occasion of the first sampling; a few more were carefully checked at each subsequent sampling. All but one belonged to the species E. longispiculosus, in line with its known distribution and abundance in the Schelde estuary and at the present sampling site (Soetaert et al. 1994, Steyaert et al. in press). For all our experiments, we selected 'large' individuals, i.e., fourth-stage juveniles and adults. Average measures

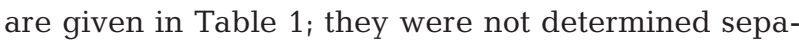
rately for each experiment. For extraction of nematodes from the sediment, sediment was resuspended in habitat water and vigorously mixed, and the supernatant was decanted over a $63 \mu \mathrm{m}$ mesh sieve. Nematodes were handpicked on the tip of a needle, transferred to filtered habitat water and stored overnight at $4^{\circ} \mathrm{C}$ before the experiments. This procedure strongly reduced the risk of cotransferring ciliates with the nematodes and allowed the transfer of all predators to a single experimental unit within $10 \mathrm{~min}$. At the same time starvation was minimal.

Prey and predator abundances used in our experiments are within the range of abundances of ciliates and nematodes in the field.

General experimental conditions and statistical evaluation. Sediment (median grain size $168 \mu \mathrm{m}$ ) from the sampling site was used as a substratum in our experiments. It was washed with running tap water over a $53 \mu \mathrm{m}$ sieve and oven sterilized at $170^{\circ} \mathrm{C}$ for $4 \mathrm{~h}$. One gram aliquots of dry sediment were transferred to $2 \mathrm{ml}$ screw-capped test tubes and rehydrated by the addition of $600 \mu \mathrm{l}$ of ciliate suspension. This resulted in approximately $1 \mathrm{ml}$ of wet sediment. The tubes were then acclimated in an incubator to the experimental temperature $\left(16^{\circ} \mathrm{C}\right.$ unless stated otherwise) for at least $2 \mathrm{~h}$. Predatory nematodes (30 per experimental unit, unless stated otherwise) were manually transferred to the tubes at Time 0 . Control tubes received no nematodes. Grazing and control tubes were incubated horizontally for $24 \mathrm{~h}$ in the dark. Incubations were stopped 
by the addition of $1 \mathrm{ml}$ of ice cold glutaraldehyde to a final concentration of $2 \%$. For each prey species or abundance (see Table 2), 3 or 4 extra replicate tubes were preserved at Time 0 to determine exact initial ciliate densities. Just before cell counts, Rose Bengal was added to stain the ciliates. The samples were homogenized and a $1 \mathrm{ml}$ subsample was withdrawn just after settling of the sand particles. Ciliates were counted under a light microscope at $100 \times$ magnification in at least $350 \mu$ of this supernatant using a SedgwickRafter cell. In each experiment, we used 3 or 4 replicate grazing tubes for each treatment (see below and in Table 2) and 3 or 4 control incubations. All samples were analyzed within $1 \mathrm{wk}$ after termination of the experiment.

Predation rates were calculated according to Frost (1972), using the following equations:

$$
\begin{gathered}
I=\frac{g \times C}{P} \\
g=\ln \left(\frac{C 2}{C 2^{*}}\right) \times t^{-1} \\
C=\frac{C 2^{*}-C 1}{\ln C 2^{*}-\ln C 1}
\end{gathered}
$$

Table 2. Summary of the experiments and the experimental conditions. Predator abundance (number of ind. $\mathrm{ml}^{-1}$ ) is given in brackets. Prey species with the same

\begin{tabular}{|c|c|c|c|}
\hline $\begin{array}{l}\text { Predator species } \\
\left(\text { ind. } \mathrm{ml}^{-1} \text { ) }\right.\end{array}$ & Prey species & $\begin{array}{l}\text { Mean initial prey } \\
\text { abundance(s) } \\
\text { (ind. } \mathrm{ml}^{-1} \text { ) }\end{array}$ & $\begin{array}{l}\text { Temp. } \\
\left({ }^{\circ} \mathrm{C}\right)\end{array}$ \\
\hline \multicolumn{4}{|l|}{ Expt 1} \\
\hline \multirow[t]{2}{*}{ Enoploides (35) } & Euplotes bisulcatus ${ }^{\mathrm{a}}$ & 589 & 16 \\
\hline & Cyclidium sp. $1^{\mathrm{a}}$ & 301 & 16 \\
\hline \multirow[t]{2}{*}{ Nematode mixture (45) } & Euplotes bisulcatus ${ }^{\mathrm{b}}$ & 589 & 16 \\
\hline & Cyclidium sp. $1^{\mathrm{b}}$ & 301 & 16 \\
\hline \multicolumn{4}{|l|}{ Expt 2} \\
\hline \multirow[t]{5}{*}{ Enoploides (30) } & Cyclidium sp. 1 & $168-962$ & 16 \\
\hline & Cyclidium sp. 2 & $462-2024$ & 16 \\
\hline & Euplotes mutabilis & $428-1745$ & 16 \\
\hline & Aspidisca sp. ${ }^{\mathrm{c}}$ & 251 & 16 \\
\hline & Chlamydodon triquetrus & 184 & 16 \\
\hline \multicolumn{4}{|l|}{ Expt 3} \\
\hline Enoploides (30) & Cyclidium sp. $13 \xi$ & $387-908-2426-5739$ & 16 \\
\hline \multicolumn{4}{|l|}{ Expt 4} \\
\hline \multirow[t]{2}{*}{ Enoploides (30) } & Euplotes mutabilis ${ }^{\mathrm{d}}$ & 2330 & 16 \\
\hline & Monhystera sp. ${ }^{\mathrm{d}}$ & $0-10-30-60-100$ & 16 \\
\hline \multicolumn{4}{|l|}{ Expt 5} \\
\hline Enoploides $(10-30-45-60)$ & Cyclidium sp. 1 & 5435 & 16 \\
\hline Enoploides (30) & Cyclidium sp. 1 & 5435 & $10-22$ \\
\hline Enoploides $(10-30-45-60)$ & Euplotes mutabilis & 2758 & 16 \\
\hline Enoploides (30) & Euplotes mutabilis & 2758 & $10-22$ \\
\hline
\end{tabular}
superscripted letter were simultaneously offered to the predators. Enoploides: Enoploides longispiculosus where $I$ is predation rate (ciliates predator ${ }^{-1} \mathrm{~h}^{-1}$ ), $g$ is grazing coefficient $\left(\mathrm{h}^{-1}\right), t$ is incubation period $(=24 \mathrm{~h})$, $C$ is mean ciliate abundance during the incubation (assuming exponential increase or decrease of abundances during the incubation period), $P$ is predator abundance (ind. $\mathrm{ml}^{-1}$ ), C1 is initial ciliate abundance, and $C 2$ and $C 2{ }^{*}$ are ciliate abundance in control and grazing tubes, respectively, at the end of the incubation period. All ciliate abundances are expressed as number of cells $\mathrm{ml}^{-1}$. Replicate initial and control abundance values were averaged for the calculations and predator mortality was assumed to be insignificant. Predation rates were calculated only when the difference in ciliate abundance between grazing and control tubes proved significant ( $t$-test). Betweentreatment differences in predation rates were tested using 1-way ANOVA. The Student-Newman-Keuls multiple comparisons test was used for post hoc pairwise comparisons. Statistical analyses were performed with STATISTICA 5.1 for Windows (StatSoft Inc., Tulsa, OK, USA). Data were $\log (x+1)$ transformed where necessary to meet the assumptions of normality and homogeneity of variances.

Feeding experiments. Our first experiment tested whether nematodes from the sampling site were capable of reducing ciliate numbers at all. To this end, a mixture of 2 ciliate species, Euplotes bisulcatus and Cyclidium sp. 1, was incubated with Enoploides longispiculosus or with a mix of other nematodes, most of which were deposit feeders (Moens \& Vincx 1997), as candidate predators. Predator density was 35 or 45 nematodes per grazing tube, respectively (Table 2). Prey preference was analyzed using Chesson's $\alpha$ selectivity index (Chesson 1983). The null hypothesis for no preference (i.e., $\alpha_{1}=\alpha_{2}=0.5$ ) was tested by calculating a $t$-statistic (Chesson 1983).

In the first experiment we found no grazing of the mix of (mainly depositfeeding) nematodes on ciliates. Therefore, all subsequent experiments used Enoploides longispiculosus as the predator. In a second experiment, the susceptibility of 5 ciliate species ( $\mathrm{Cy}$ clidium sp. 1, Cyclidium sp. 2, Euplotes mutabilis, Chlamydodon triquetrus and Aspidisca sp.) to predation by E. longispiculosus was tested (Table 2). Two different densities of Cyclidium sp. 1, Cyclidium sp. 2 and E. mutabilis were used. The remaining 2 species were reared in a mixed culture yield- 
ing only low abundances. Hence, they were offered to E. longispiculosus as a 2-species mix at a single density.

The results of the second experiment suggested that predation rates depend on prey density. This effect was examined in more detail in a third experiment with Cyclidium sp. 1 as the prey species (Table 2). Initial ciliate abundances were $387 \pm 125,908 \pm 168$, $2426 \pm 355$ and $5739 \pm 232$ cells $\mathrm{ml}^{-1}$. Ingestion rates were related to mean ciliate abundances within the incubation period, as estimated according to Eq. (3).

The main question in the fourth experiment was whether and how predation rates of Enoploides longispiculosus on ciliates would be affected by the presence of alternative prey, in casu nematodes. This is of particular relevance to the field situation, where alternative prey is always available. Monhystera sp., a bacterivorous nematode species heavily preyed upon by E. longispiculosus (Moens et al. 2000), was used as nematode prey. These were handpicked from monospecific cultures, originating from a saltmarsh in the polyhaline reach of the Schelde estuary close to the Molenplaat (see Moens \& Vincx 1998 for details on culture conditions). Euplotes mutabilis was used as the prey ciliate. Initial ciliate abundance was constant $\left(2330 \pm 132 \mathrm{ml}^{-1}\right)$, whereas 5 different prey nematode densities were used: 0, 10, 30, 60 and 100 nematodes per grazing tube (Table 2). Controls contained ciliate and nematode prey at the same densities as in the grazing tubes but did not contain the predator, $E$. longispiculosus. At the end of the incubation, ciliate numbers in control tubes without and with Monhystera sp. at different densities did not differ significantly (ANOVA, $p=0.16$ ), suggesting no interaction between the prey organisms. Predation rates of E. longispiculosus on Monhystera sp. were also determined in this experiment. Part of the prey nematodes was counted from the subsamples withdrawn for ciliate counts. The remainder was extracted by decantation after sample homogenization in $1 \mathrm{ml}$ of filtered habitat water. This procedure was repeated 6 times and nematodes were counted in the pooled supernatant using a dissecting microscope. Carbon ingestion was estimated using an individual carbon content of $0.047 \mu \mathrm{g} \mathrm{C}$ for Monhystera sp. (Moens et al. 2000, our Table 1). Prey preference was analyzed as described above. Chesson's $\alpha$ selectivity index is unaffected by the relative abundance of food types, thus allowing meaningful comparisons between treatments (Lechowicz 1982).

A final set of experiments aimed at extending the relevance of the ob- served predation rates on ciliates to field conditions, where, among other factors, predator abundance and temperature are not constant. The separate effects of predator density and temperature on predation rates of Enoploides longispiculosus on Cyclidium sp. 1 and Euplotes mutabilis were tested (Table 2). Four predator densities were used: 10, 30, 45 or 60 per grazing tube. Grazing and control tubes were incubated at $16^{\circ} \mathrm{C}$. Additional replicate grazing tubes with 30 predator nematodes and associated control tubes were incubated at 10 and $22^{\circ} \mathrm{C}$. Predation rates at 10 and $22^{\circ} \mathrm{C}$ were then compared with rates obtained at $16^{\circ} \mathrm{C}$ with a predator density of 30 ind. $\mathrm{ml}^{-1}$.

\section{RESULTS}

In the first experiment, the mix of (mainly depositfeeding) nematodes did not significantly reduce Euplotes bisulcatus nor Cyclidium sp. 1 densities during the $24 \mathrm{~h}$ incubation period (data not shown). Predation of Enoploides longispiculosus on E. bisulcatus and Cyclidium sp. 1, on the other hand, was significant. Predation rates were $0.15 \pm 0.07$ and $0.21 \pm 0.07$ ciliates predator $^{-1} \mathrm{~h}^{-1}$ for E. bisulcatus and Cyclidium sp. 1, respectively. Since E. bisulcatus and Cyclidium sp. 1 were offered as a mixture to E. longispiculosus, a predator preference could be analyzed. E. longispiculosus preferred Cyclidium to Euplotes, as more Cyclidium was captured than expected based on the relative prey proportions offered. This is also reflected by the value of Chesson's selectivity index $\alpha$ for Cyclidium $(0.74 \pm 0.11)$, which significantly exceeded 0.5 ( $t$-tests of Chesson's index versus 0.5 , $\mathrm{df}=3, \mathrm{p}<0.05$ ).

Susceptibility of different ciliate species to predation by Enoploides longispiculosus was evaluated in the second experiment (Table 3). For Cyclidium sp. 1, a

Table 3. Predation of Enoploides longispiculosus on 5 ciliate species: mean $( \pm 1 \mathrm{SD}, \mathrm{n}=3)$ initial ciliate abundance and predation rate for each prey species and abundance. ns: Ciliate numbers in control and grazing tubes were not significantly different. Ciliate species with the same superscripted letter were simultaneously offered to the predators

\begin{tabular}{|lccc|}
\hline Ciliate species & $\begin{array}{c}\text { Initial abund. } \\
\left(\text { cells } \mathrm{m}^{-1} \text { ) }\right.\end{array}$ & $\begin{array}{c}\text { Predation rate } \\
\text { Cells predator }{ }^{-1} \mathrm{~h}^{-1}\end{array}$ & $\mu \mathrm{g} \mathrm{C}$ predator $^{-1} \mathrm{~h}^{-1}$ \\
\hline Cyclidium sp. 1 & $168 \pm 29$ & $0.19 \pm 0.01$ & $0.001 \pm 0.0001$ \\
& $962 \pm 213$ & $\mathrm{~ns}$ & \\
Cyclidium sp. 2 & $462 \pm 36$ & $\mathrm{~ns}$ & \\
& $2024 \pm 83$ & $\mathrm{~ns}$ & \\
Euplotes mutabilis & $428 \pm 65$ & $0.22 \pm 0.03$ & $0.046 \pm 0.007$ \\
& $1745 \pm 188$ & $1.08 \pm 0.11$ & $0.221 \pm 0.022$ \\
Aspidisca sp. $^{\text {a }}$ & $251 \pm 18$ & $0.18 \pm 0.02$ & $0.002 \pm 0.0002$ \\
Chlamydodon triquetrus $^{\mathrm{a}} 184 \pm 115$ & $0.20 \pm 0.02$ & $0.038 \pm 0.004$ \\
\hline
\end{tabular}


significant predator effect was only found for the lower density tested (predation rate: $0.19 \pm 0.01$ ciliates predator $^{-1} \mathrm{~h}^{-1}$ ). At the higher Cyclidium sp. 1 density, the average ciliate abundance in grazing tubes was considerably lower than in control tubes (1137 vs $1723 \mathrm{ml}^{-1}$ ), but variability between replicates was high, giving rise to a non-significant difference between the means. Cyclidium sp. 2, the smallest of the ciliate species tested, was not grazed upon by E. longispiculosus at either of the densities used. Euplotes mutabilis numbers were significantly reduced by E. longispiculosus at high as well as low densities. The predation rate increased from $0.22 \pm 0.03$ to $1.08 \pm 0.11$ ciliates predator $^{-1} \mathrm{~h}^{-1}$, for a 4 -fold increase in initial ciliate abundance (on average 428 and 1745 ciliates $\mathrm{ml}^{-1}$, respectively). Densities of Aspidisca sp. and Chlamydodon triquetrus, offered as a mixture, were significantly reduced by E. longispiculosus during the incubation period. Predation rates were $0.18 \pm 0.02$ ciliates $\mathrm{ml}^{-1}$ for Aspidisca sp. and $0.20 \pm 0.02$ ciliates $\mathrm{ml}^{-1}$ for $C$. triquetrus. No preference for either of the ciliates was observed in this case. Carbon ingestion ranged from 0.001 to $0.221 \mu \mathrm{g}$ C predator ${ }^{-1} \mathrm{~d}^{-1}$ and was lowest for Cyclidium sp. 1 and highest for E. mutabilis as prey species.

In the third experiment, a positive relation between predation rates of Enoploides longispiculosus and the density of its prey (Cyclidium sp. 1) was found (Fig. 1), but there was no saturation of the predation rate over the range of prey densities tested. Predation rates increased from $0.41 \pm 0.14$ to $4.1 \pm 1.5$ ciliates predator $^{-1} \mathrm{~h}^{-1}$ over a range of $759 \pm 79$ to $5138 \pm 677$ ciliates $\mathrm{ml}^{-1}$. Corresponding carbon uptake rates were 0.003 to $0.027 \mu \mathrm{g}$ C predator ${ }^{-1} \mathrm{~d}^{-1}$.

In a fourth experiment, the effect of the presence of alternative food (the bacterivorous nematode Monhys-

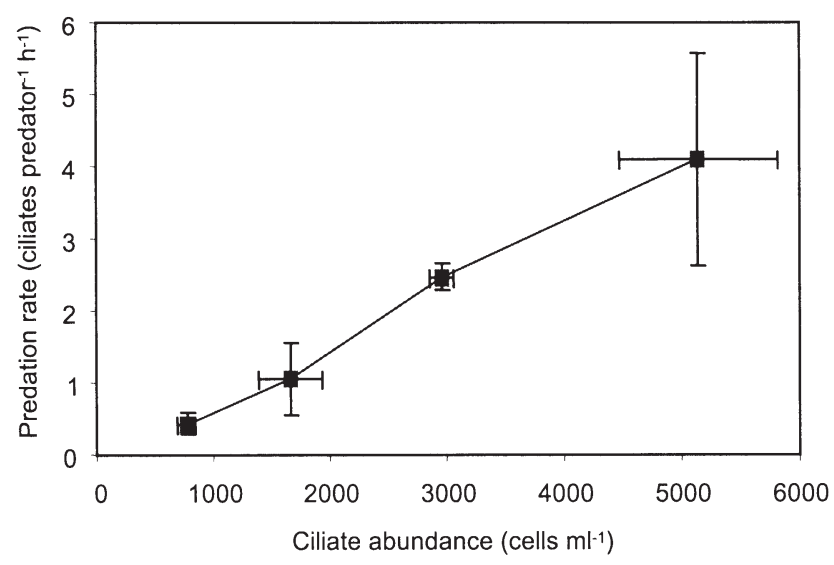

Fig. 1. Predation rates of Enoploides longispiculosus as a function of mean abundance of Cyclidium sp. 1 over the experimental period. Mean $\pm 1 \mathrm{SD}(\mathrm{n}=3)$
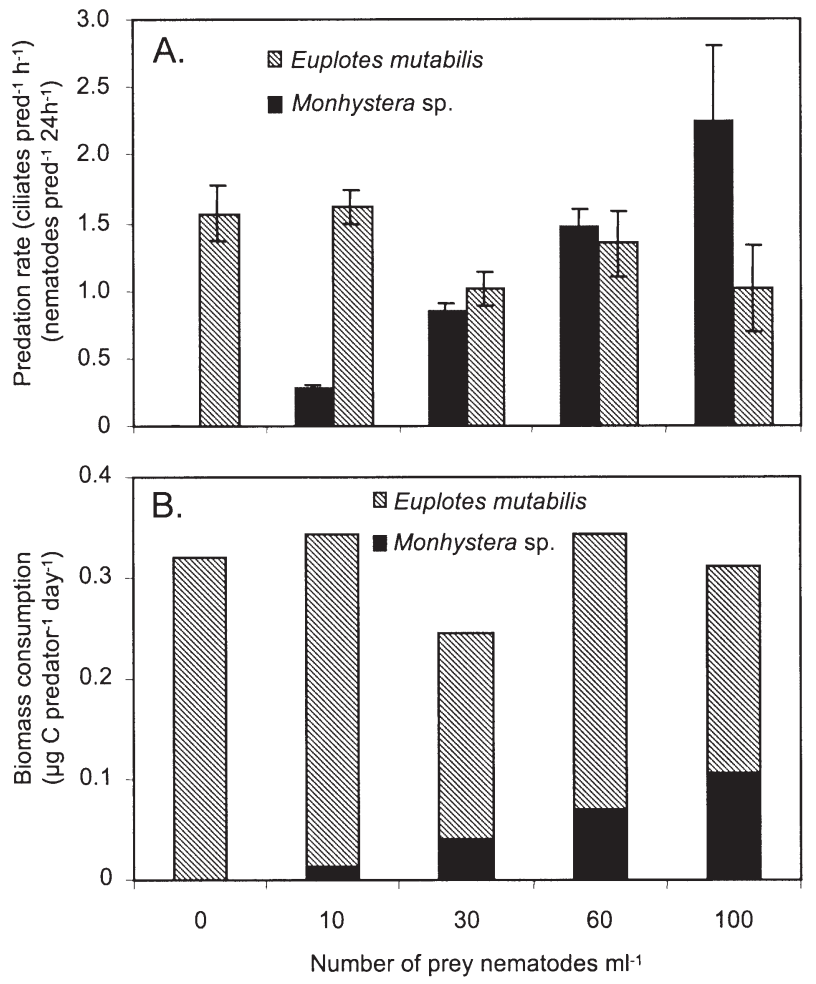

Fig. 2. (A) Predation rates of Enoploides longispiculosus on ciliate (Euplotes mutabilis) and nematode (Monhystera sp.) prey (mean $\pm 1 \mathrm{SD}, \mathrm{n}=3$ ), and (B) total daily biomass consumption (ciliate + nematode prey) for different prey nematode abundances. Initial ciliate abundances were constant $\left(2330 \pm 132 \mathrm{ml}^{-1}\right)$. pred: predator

teria sp.) on predation rates of Enoploides longispiculosus on ciliate prey (Euplotes mutabilis) was considered. E. mutabilis numbers were significantly reduced by E. longispiculosus in the absence as well as in the presence of nematode prey (all p < 0.01). In the absence of nematode prey, the predation rate was $1.6 \pm$ 0.2 (Fig. 2A). The same predation rate was found with 10 prey nematodes $\mathrm{ml}^{-1}$. In the presence of 30,60 or 100 Monhystera sp. $\mathrm{ml}^{-1}$, predation rates were lower ( 1 to 1.3 ciliates predator ${ }^{-1} \mathrm{~h}^{-1}$ ) than in the absence of prey nematodes, although this difference was not always significant ( $\mathrm{p}<0.05$ for 30 or 100 prey nematodes $\mathrm{ml}^{-1}, \mathrm{p}>0.05$ for 60 prey nematodes $\mathrm{ml}^{-1}$ ). The predation rate of $E$. longispiculosus on the nematode Monhystera sp. increased significantly from $0.28 \pm$ 0.02 nematodes predator ${ }^{-1} 24 \mathrm{~h}^{-1}$ at an initial prey nematode density of $10 \mathrm{ind} . \mathrm{ml}^{-1}$, to $2.26 \pm 0.54$ nematodes predator ${ }^{-1} 24 \mathrm{~h}^{-1}$ at an initial prey nematode density of 100 ind. $\mathrm{ml}^{-1}$ (all $\mathrm{p}<0.05$; Fig. 2A). Total biomass consumption (ciliate plus nematode prey) ranged from $0.25 \pm 0.03$ to $0.34 \pm 0.05 \mu \mathrm{g} C$ predator ${ }^{-1} \mathrm{~d}^{-1}$ and was not significantly affected by nematode prey density ( $p=0.21$; Fig. $2 B$ ). The predator showed a preference 


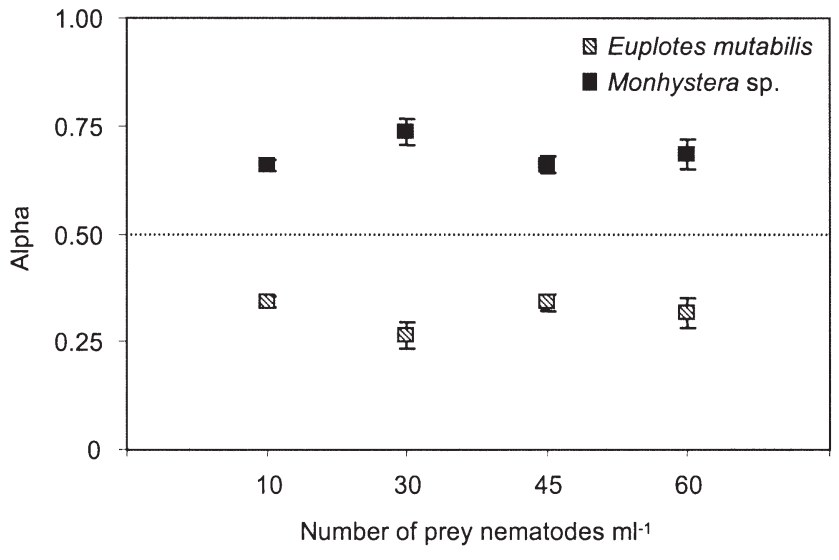

Fig. 3. Chesson's coefficient of selectivity of Enoploides longispiculosus for a ciliate (Euplotes mutabilis) and a nematode (Monhystera sp.) prey species $( \pm 1 \mathrm{SD}, \mathrm{n}=3$ ) for different Monhystera sp. abundances. E. mutabilis abundance was constant. The dashed line represents neutral selection

for nematode over ciliate prey: $\alpha$ for Monhystera sp. always significantly exceeded 0.5 ( $t$-tests of Chesson's index versus $0.5, \mathrm{df}=2$, all $\mathrm{p}<0.02$; Fig. 3). This selectivity was independent of the relative proportion of prey types in the predator's ration.

In a last set of experiments the separate effects of predator density and temperature on predation rates of Enoploides longispiculosus were tested with Cyclidium sp. 1 and Euplotes mutabilis as prey. Cyclidium sp. 1 was significantly reduced at all predator densities. Individual predation rates decreased significantly from $10.8 \pm 0.8$ to $2.7 \pm 0.4$ ciliates predator ${ }^{-1} \mathrm{~h}^{-1}$ with an increase in predator abundance from 10 to $60 \mathrm{ind}$. $\mathrm{ml}^{-1}$ (all $\mathrm{p}<0.05$; Fig. 4A). Total consumption of ciliate prey was highest at 45 predators $\mathrm{ml}^{-1}$, but pairwise differences for 30,45 or 60 predators $\mathrm{ml}^{-1}$ were not significant ( $p>0.05$; Fig. 4B). Ciliate consumption by 10 predators $\mathrm{ml}^{-1}$ was significantly lower than that by higher predator densities. Ten predators $\mathrm{ml}^{-1}$ did not significantly reduce numbers of $E$. mutabilis, but all higher predator densities did. Predation rates on $E$. mutabilis were not significantly affected by an increase in predator density from $30 \mathrm{ml}^{-1}$ to 45 and $60 \mathrm{ml}^{-1}$ ( $\mathrm{p}=0.18$; Fig. $4 \mathrm{~A}$ ), although the predation rate for 30 predators $\mathrm{ml}^{-1}$ was higher (1.1 ciliates predator ${ }^{-1}$ $\mathrm{h}^{-1}$ ) than for higher predator densities (0.7 ciliates predator $\left.^{-1} \mathrm{~h}^{-1}\right)$. No significant differences $(p>0.1)$ were detectable between the total ciliate consumption by 30,45 or 60 predators (Fig. 4B).

The effect of temperature on predation rates was most pronounced with Cyclidium sp. 1 as a prey species. Densities of this species were not significantly reduced by Enoploides longispiculosus at $10^{\circ} \mathrm{C}$, but they were at 16 and $22^{\circ} \mathrm{C}$. At $22^{\circ} \mathrm{C}$, the mean predation rate was $25 \%$ higher than at $16^{\circ} \mathrm{C}$, but this difference
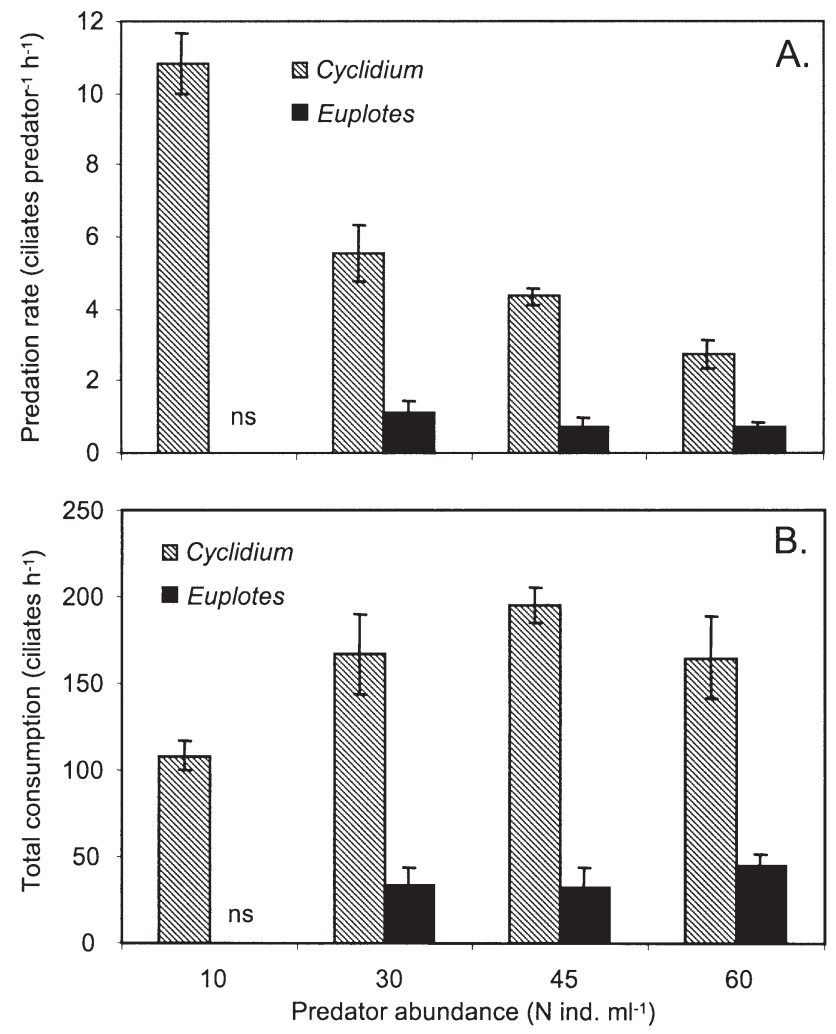

Fig. 4. (A) Predation rates of Enoploides longispiculosus on Cyclidium sp. 1 and Euplotes mutabilis (mean $\pm 1 \mathrm{SD}, \mathrm{n}=3$ ), and (B) total consumption of all predators for both prey species at different E. longispiculosus abundances

was not significant ( $\mathrm{p}=0.26$; Fig. 5). Euplotes mutabilis numbers were significantly reduced at all temperatures tested, but temperature differences did not result in significantly different predation rates $(p=0.35$; Fig. 5). On average, predation rates on E. mutabilis were slightly higher at $16^{\circ} \mathrm{C}$ than at 10 and $22^{\circ} \mathrm{C}$.

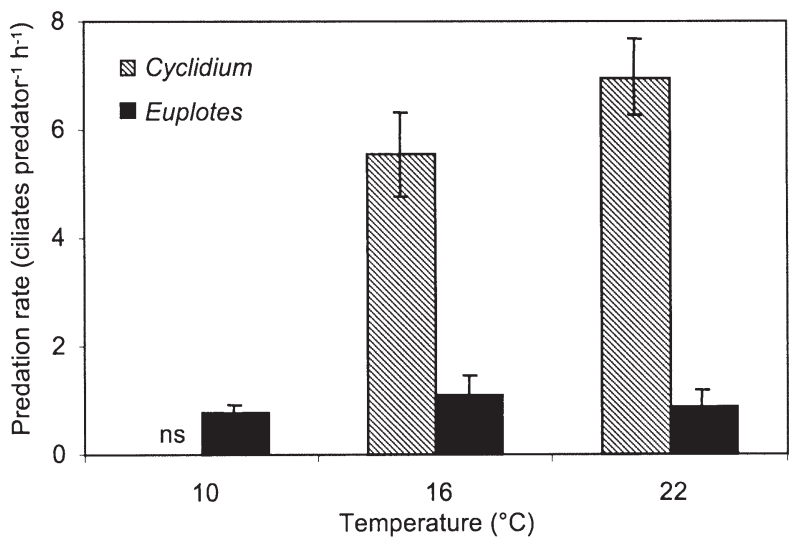

Fig. 5. Predation rates of Enoploides longispiculosus on Cyclidium sp. 1 and Euplotes mutabilis (mean $\pm 1 \mathrm{SD}, \mathrm{n}=3$ ) at different temperatures 


\section{DISCUSSION}

Our results show that the predatory nematode Enoploides longispiculosus significantly reduced densities of 5 out of 6 ciliate species offered as prey. These ciliates belonged to different taxonomic groups, were of different sizes, and included swimming as well as creeping, and bacterivorous as well as a strictly herbivorous species. Since E. longispiculosus, a voracious predator of several small metazoans (Moens \& Vincx 1997, Moens et al. 1999, 2000), probably does not feed on bacteria nor diatoms (Moens et al. 1999), resource competition between nematodes and ciliates is a highly improbable explanation for the observed decline in ciliate numbers. Furthermore, we regularly observed fragments of Euplotes cells in grazing tubes (never found in controls without predators), indicating capture and incomplete uptake of these large ciliates by E. longispiculosus. In combination with the design of our experiments, this leaves little doubt that the observed reductions in ciliate densities resulted from direct predation by E. longispiculosus on ciliates. The mix of (mainly deposit-feeding) nematodes used in our first experiment and the bacterivorous nematode Monhystera sp. offered as alternative prey to E. longispiculosus did not prey on the ciliate species used in our experiments. In contrast to E. longispiculosus, which has a buccal cavity armed with teeth and mandibles used to tear apart variably sized prey items, these nematodes have an unarmed mouth and are probably incapable of ingesting food particles exceeding the size of their widened buccal cavity (Moens \& Vincx 1997).

To our knowledge, our experiments provide the first quantitative data on predation of benthic ciliates by nematodes. Anecdotal observations of a few nematode species ingesting ciliates in cultures have been reported (von Thun 1968, Bouwman et al. 1984, Moens \& Vincx 1997, E. Olafsson pers. comm.), but predation rates were not determined. Walters \& Moriarty (1993) found indirect evidence for consumption of marine benthic ciliates and flagellates by a meiofaunal community dominated by nematodes and copepods. Epstein \& Gallager (1992) showed variable effects of an increase in nematode numbers on different ciliate species from a sandflat, with densities of only 2 out of 7 ciliate species examined being negatively affected. However, there was no unequivocal evidence that direct predation by nematodes was involved in these cases.

The 'standard' conditions used in our experiments (i.e., 30 Enoploides longispiculosus ind. $\mathrm{ml}^{-1}, 16^{\circ} \mathrm{C}$ ) reflect late spring to early autumn field conditions at our sampling station on the Molenplaat. The temperature of the Schelde water near the Molenplaat is gen- erally $16^{\circ} \mathrm{C}$ or more between May and October. During this part of the year, E. longispiculosus was found in densities of about 15 to 30 ind. $\mathrm{ml}^{-1}$ in the upper 1.5 to $2 \mathrm{~cm}$ of the sediment at this site (Steyaert et al. in press) and dominates the nematode community; this dominance was confirmed at each of our sampling dates. Our experiments give only a limited insight into the role of temperature and predator abundance. For both Cyclidium sp. 1 and Euplotes mutabilis, predation rates of E. longispiculosus at $22^{\circ} \mathrm{C}$ did not differ significantly from those at $16^{\circ} \mathrm{C}$. Whereas total ciliate consumption at low predator abundance $\left(10 \mathrm{ml}^{-1}\right)$ was lower than with 30 predators $\mathrm{ml}^{-1}$, no significant differences between total consumption by 30,45 or 60 predators $\mathrm{ml}^{-1}$ were detectable. Temperature in the field rises above $16^{\circ} \mathrm{C}$ in late spring to autumn; predator densities are probably quite variable due to patchiness (Arlt 1973). Even so, our experiments suggest a limited influence of such temperature and predator density fluctuations. Hence, predation rates from our experiments under standard conditions may well be used to estimate the potential impact of nematode predation on ciliates at the study site.

In our functional response experiment, predation rates of Enoploides longispiculosus increased with increasing ciliate (Cyclidium sp. 1) density and hence biomass, but there was no saturation within the range of prey abundances used. Although the highest Cyclidium sp. 1 density used in this experiment was higher than field densities of ciliates, ciliate biomasses, viz. 0.1 to $1.6 \mu \mathrm{g} \mathrm{C} \mathrm{ml}^{-1}$, were lower than biomasses found at our sampling site ( 2 to $3.5 \mu \mathrm{g} \mathrm{C} \mathrm{ml}^{-1}$ in the upper $2 \mathrm{~cm}$ in late spring to autumn) due to the relatively small size of Cyclidium sp. 1. The range of ciliate biomasses used in all our experiments conducted under standard conditions, including those with the large Euplotes mutabilis as prey, encompassed a broader range of ciliate biomasses, up to biomasses exceeding those encountered at the Molenplaat. These data show an increase in predation rates up to a biomass of $20 \mu \mathrm{g} \mathrm{C} \mathrm{ml}^{-1}$ (Fig. 6), without a clear sign of saturation up to a ciliate biomass of at least $4 \mu \mathrm{g} \mathrm{C} \mathrm{ml}^{-1}$. On the basis of these results and field biomasses for ciliates (see above), a predation rate of about $0.04 \mu \mathrm{g} \mathrm{C}$ predator $^{-1} \mathrm{~d}^{-1}$ can be expected in the field (Fig. 6). Twenty predators $\mathrm{ml}^{-1}$ would then consume about $0.8 \mu \mathrm{g}$ ciliate $\mathrm{C} \mathrm{ml}^{-1} \mathrm{~d}^{-1}$. The impact of this predation on the ciliate community can only be assessed after comparison with ciliate production rates. Maximum growth rates $\left(\mu_{\max }\right)$ for ciliates can be estimated using a multiple regression equation based on extensive laboratory data (Müller \& Geller 1993), which relates temperature and species size to growth rate. Maximum production of a mixed assemblage of ciliates can then be estimated by addition of the products of growth rate 


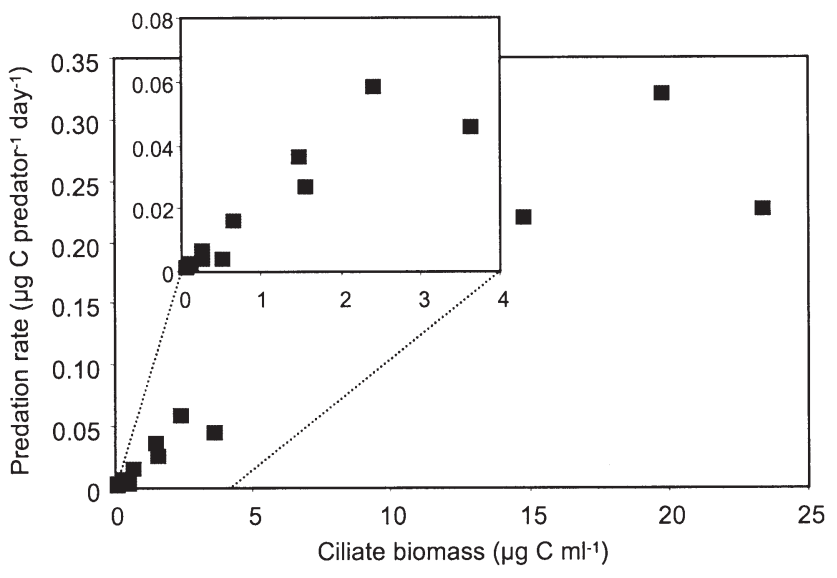

Fig. 6. Predation rate as a function of ciliate biomass for all experiments conducted under standard experimental conditions

with biomass for each species. For the ciliate community of the upper $2 \mathrm{~cm}$ at our Molenplaat station, in late spring to early autumn, a maximum production of about 2 to $4.5 \mu \mathrm{g} \mathrm{C} \mathrm{ml} \mathrm{C}^{-1}$ is obtained in this way. Given the above-mentioned estimated consumption of ciliate carbon in the field, nematode grazing would amount to about 18 to $40 \%$ of daily ciliate production. This is a conservative estimate, since growth rates in the field are probably lower than the estimated rates (e.g., because of food limitation). In pelagic communities, for instance, in situ ciliate growth rates were found to be 2 to 5 times lower than the estimated maxima (Taylor \& Johannsson 1991, Leakey et al. 1994, Macek et al. 1996). Nematode grazing may thus be an important, if not the major, fate of ciliate production in intertidal sediments at our sampling site on the Molenplaat.

Apart from regulating ciliate biomass, nematode predation may also affect ciliate community composition. Only 1 out of 6 ciliate species used in our experiments was not consumed by Enoploides longispiculosus, namely Cyclidium sp. 2, the smallest ciliate species in our experiments. When a mix of Euplotes bisulcatus and Cyclidium sp. 1 was offered as prey in our experiments, however, E. longispiculosus significantly selected for the smaller Cyclidium sp. 1. Particle size is often an important factor determining food selection, and observations indicate that next to an upper size limit, there may also be a lower size limit for particle selection in nematodes (Cheng et al. 1979). In addition to size, the swimming behavior of ciliate prey may also influence its susceptibility to predation by metazoans (Jack \& Gilbert 1993, Rabette et al. 1998). In the field, many more species co-occur and shifts in species composition due to differences in predation rates are likely to occur due to selective predation on certain species. This is in agreement with the results of Epstein
\& Gallagher (1992), who found changes in relative species abundances in response to an increase in nematode density.

In the field, ciliates are not the only prey available to predacious nematodes. Higher predation rates on other prey types, when both are available, could have a profound effect on the impact of nematode predation on ciliates. Nematodes of the genus Enoploides have been shown to forage on other nematodes as well as on oligochaetes and probably other small metazoans as well (Moens \& Vincx 1997, Moens et al. 1999). At the Molenplaat, as in most estuarine intertidal sediments, nematodes are the dominant meiofauna $199 \%$ in terms of abundance at the study site, M. Steyaert unpubl. data). In our experiments with both nematode (Monhystera sp.) and ciliate (Euplotes mutablis) prey, predation rates on ciliates decreased only in the presence of at least 30 nematode prey $\mathrm{ml}^{-1}$, and even then, the difference was small. Even so, a preference for nematode over ciliate prey was found. However, further research will have to elucidate whether this preference is of general relevance or merely holds for the specific prey species combination used here. Moreover, production rather than extant biomass probably determines the relative contribution of different prey types to the predator's ration, and hence the impact on their respective populations. In the depth stratum where Enoploides longispiculosus occurs (upper $2 \mathrm{~cm}$ ), the biomass of potential prey nematodes is about $5.2 \mu \mathrm{g} \mathrm{C}$

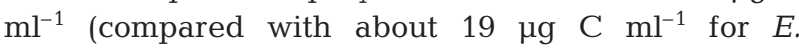
longispiculosus) at the study site (M. Steyaert unpubl. data). Assuming an annual production/biomass ratio of 9 (Gerlach 1971), prey nematode production in this stratum can be expected to be in the order of $45 \mu \mathrm{g} \mathrm{C}$ $\mathrm{ml}^{-1} \mathrm{yr}^{-1}$ or about $0.13 \mu \mathrm{g} \mathrm{C} \mathrm{ml} \mathrm{Cl}^{-1} \mathrm{~d}^{-1}$. This is several times lower than estimates of ciliate production at this site. This difference is expected given the small difference in standing stock between nematodes and ciliates and the generally much higher metabolic rate of protozoa. If we assume for E. longispiculosus (1) 1 to 3 generations annually (e.g., Wieser \& Kanwisher 1960, Schütz 1966, Skoolmun \& Gerlach 1971, Lorenzen 1974, Smol et al. 1980); (2) a life cycle turnover of 3, as for other nematodes (Gerlach 1971); (3) a production efficiency ( $P$ [roduction]/A[ssimilation], with $A=P+$ $R$ [espiration]) of $75 \%$ (mean value based on Heip et al. 1985 and references therein); and (4) an assimilation efficiency $(A / C$ [onsumption]) ranging from 12 (Duncan et al. 1974) to $60 \%$ (Marchant \& Nicholas 1974), then a predatory nematode with a mean individual biomass of $1.2 \mu \mathrm{g} \mathrm{C}$ (Table 1) has carbon requirements of at least 8 (for 1 generation annually and $A / C=60 \%$ ) and at most $120 \mu \mathrm{g} \mathrm{C} \mathrm{yr}{ }^{-1}$ (for 3 generations annually and $A / C=12 \%$ ). This corresponds to a mean daily carbon uptake of 0.022 to $0.33 \mu \mathrm{g} C$ predator $^{-1} \mathrm{~d}^{-1}$, which 
is comparable with the carbon ingestion estimates derived from our experiments (0.001 to $0.33 \mu \mathrm{g} \mathrm{C}$ predator $^{-1} \mathrm{~d}^{-1}$ ). This comes down to a carbon flux of 0.33 to $9.9 \mu \mathrm{g} \mathrm{C} \mathrm{ml}^{-1} \mathrm{~d}^{-1}$ for the E. longispiculosus population at our sampling site at the extant summer density. Both upper and lower values are extremes (as are the experimentally determined ingestion rates), with a value of about $1.5 \mathrm{ug} \mathrm{C} \mathrm{ml}^{-1} \mathrm{~d}^{-1}$ probably being a plausible average (assuming 2 generations annually and $\mathrm{A} / \mathrm{C}=40 \%$ ). Even if we consider the prey nematode production/biomass ratio of 9 as a conservative estimate (Vranken et al. 1986), this strongly suggests that prey nematode populations at the study site on the Molenplaat provide insufficient carbon to sustain the extant predator population. Hence, at least in summer, ciliates are probably a far more important carbon source for E. longispiculosus than nematodes. This implies that carbon transfer from primary producers and bacteria to predatory nematodes may be mediated largely by the microbial food web. Comparison of these values with ciliate production also suggests that, even in the presence of alternative prey, a considerable part of ciliate production is probably consumed by E. longispiculosus in the field. The fate of predatory nematode carbon in Schelde sediments is at present not very clear. Li et al. (1996) modeled temporal fluctuations in nematode (whole community) densities at different sites in the estuary and concluded that they are regulated primarily by macrobenthic infauna. So far, there are no experimental studies supporting this claim. On the other hand, surface-dwelling meiofauna has long been shown to be important prey to epi- and hyperbenthic fish and crustaceans (see, among others, Gee 1989, Coull 1990). Harpacticoid copepods are generally considered to be more susceptible to predation by sediment-dwelling fauna, but this view may be partly biased because nematode remains are not easily recognizable in gut content analyses. The large (3.3 to $4.2 \mathrm{~mm}$ long, 76 to $145 \mu \mathrm{m}$ wide) predacious Mesacanthion diplechma, a nematode showing clear preference for superficial sediment layers, was disproportionately abundant in sand goby guts in sediments of the Southern Bight of the North Sea and of the nearby Oosterschelde Estuary (Hamerlynck \& Vanreusel 1993). Whether such trophic relations also exist in the Schelde estuary and, if so, how important they are in terms of carbon fluxes from the microbial food web to higher trophic levels remains to be established.

Our experiments, as well as the situation at the sampling site on the Molenplaat, are, of course, a case study, the general importance of which remains to be established. However, densities of ciliates at our study site are generally comparable with those found in other marine and estuarine fine sandy sediments (Fenchel 1967, Al-Rasheid \& Sleigh 1995, Epstein
1997, Wickham et al. 2000). Enoploides longispiculosus and other members of this genus occur in high densities (comparable with those found on the Molenplaat) in this type of sediments in the North Sea (Skoolmun \& Gerlach 1971, Vincx et al. 1990), the Schelde estuary and some other European estuaries (Platt \& Warwick 1983, Li \& Vincx 1993, Soetaert et al. 1994, 1995). Since we know of no other reports of a relative dominance similar to that found in the upper $2 \mathrm{~cm}$ of the fine sandy sediment on the Molenplaat, the (nematode) prey limitation of E. longispiculosus at this site may be unusual. However, Warwick (1971) found that nematodes in muddy sediments in the Exe estuary tended to be small and mainly deposit feeders, while species from sandy sediments tended to be predators or epigrowth feeders with long bodies. Hence, density and relative abundance of supposedly predatory nematodes are probably typically much higher in sandy than in silty sediments. Hence, in view of the generally high densities and biomasses of ciliates as well as of predatory nematodes in sandy sediments, nematode predation on ciliates probably constitutes a significant trophic link in many estuarine and marine sediments.

Acknowledgements. We thank the Netherlands Institute of Ecology-Centre for Estuarine and Coastal Ecology (NIOOCEMO) and the crew for the use of the RV 'Luctor'. Christine Van der heyden and Ilse De Mesel are thanked for their assistance in some of the laboratory experiments. Dr Karline Soetaert and Maaike Steyaert kindly provided data on nematode abundances and biomasses. I.H. acknowledges a grant from the Fund for Scientific Research-Flanders (FWO); T.M. and K.M. are postdoctoral fellows of the Fund. This research was performed in the framework of the EU Environment \& Climate program ECOFLAT (ENV4-CT96-0216), which is part of the ELOISE program (publication no. 255), FWO research project no. G.0104.99 and GOA research project no. 1205398.

\section{LITERATURE CITED}

Al-Rasheid KAS, Sleigh MA (1995) Distribution and abundance of interstitial ciliates in Southampton water in relation to physicochemical conditions, metal pollution and the availability of food organisms. Estuar Coast Shelf Sci 41:61-80

Arlt G (1973) Vertical and horizontal microdistribution of the meiofauna in the Greifswalder Bodden. Oikos 15(Suppl): 105-111

Arndt H (1993) Rotifers as predators on components of the microbial web (bacteria, heterotrophic flagellates, ciliates): a review. Hydrobiologia 255:231-246

Azam F, Fenchel T, Field JG, Gray JS, Meyer-Reil LA, Thingstad F (1983) The ecological role of water-column microbes in the sea. Mar Ecol Prog Ser 10:257-263

Børsheim KY, Bratbak G (1987) Cell volume to cell carbon conversion factors for a bacterivorous Monas sp. enriched from seawater. Mar Ecol Prog Ser 36:171-175

Bott TL, Borchardt MA (1999) Grazing of protozoa, bacteria, and diatoms by meiofauna in lotic epibenthic communi- 
ties. J N Am Benthol Soc 18:499-513

Bouwman LA, Romeyn K, Kremer DR, Van Es FB (1984) Occurrence and feeding biology of some nematode species in estuarine aufwuchscommunities. Cah Biol Mar 25: 287-303

Caron DA (1993) Enrichment, isolation, and culture of freeliving heterotrophic flagellates. In: Kemp PF, Sherr BF, Sherr EB, Cole JJ (eds) Handbook of methods in aquatic microbial ecology. Lewis Publishers, Boca Raton, p 77-89

Cheng AC, Lu NC, Briggs GM, Stokstad ELR (1979) Effect of particulate materials on population growth of the free-living nematode Caenorhabditis briggsae. Proc Soc Exp Biol Med 160:203-207

Chesson J (1983) The estimation and analysis of preference and its relationship to foraging models. Ecology 64: $1297-1304$

Coull BC (1990) Are members of the meiofauna food for higher trophic levels? Trans Am Microsc Soc 109:233-246

Dietrich D, Arndt H (2000) Biomass partitioning of benthic microbes in a Baltic inlet: relationships between bacteria, algae, heterotrophic flagellates and ciliates. Mar Biol 136: 309-322

Duncan A, Schiemer F, Klekowski RZ (1974) A preliminary study of feeding rates on bacterial food by adult females of a benthic nematode, Plectus palustris De Man 1880. Pol Arch Hydrobiol 21:237-255

Epstein SS (1997) Microbial food webs in marine sediments. II. Seasonal changes in trophic interactions in a sandy tidal flat community. Microb Ecol 34:199-209

Epstein SS, Gallagher ED (1992) Evidence for facilitation and inhibition of ciliate population growth by meiofauna and macrofauna on a temperate zone sandflat. J Exp Mar Biol Ecol 155:27-39

Fenchel T (1967) The ecology of marine microbenthos. I. The quantitative importance of ciliates as compared with metazoans in various types of sediments. Ophelia 4: $121-137$

Fenchel T (1968) The ecology of marine microbenthos. II. The food of marine benthic ciliates. Ophelia 5:73-121

Fenchel T (1969) The ecology of marine microbenthos. IV. Structure and function of the benthic ecosystem, its chemical and physical factors and the microfauna communities with special reference to the ciliated protozoa. Ophelia 6: $1-182$

Frost BW (1972) Effects of size and concentration of food particles on the feeding behavior of the marine planktonic copepod Calanus pacificus. Limnol Oceanogr 17:805-815

Gasol JM (1993) Benthic flagellates and ciliates in fine freshwater sediments: calibration of a live counting procedure and estimation of their abundances. Microb Ecol 25: $247-262$

Gee JM (1989) An ecological and economic review of meiofauna as food for fish. Zool J Linnean Soc 96:243-261

Gerlach SA (1971) On the importance of marine meiofauna for benthos communities. Oecologia 6:176-190

Hamels I, Sabbe K, Muylaert K, Barranguet C, Lucas C, Herman P, Vyverman W (1998) Organisation of microbenthic communities in intertidal estuarine flats, a case study from the Molenplaat (Westerschelde Estuary, The Netherlands). Eur J Protistol 34:308-320

Hamerlynck O, Vanreusel A (1993) Mesacanthion diplechma (Nematoda: Thoracostomopsidae), a link to higher trophic levels? J Mar Biol Assoc UK 73:453-456

Heip C, Vincx M, Vranken G (1985) The ecology of marine nematodes. Oceanogr Mar Biol Annu Rev 23:399-489

Herman PMJ, Middelburg JJ, Widdows J, Lucas CH, Heip CHR (2000) Stable isotopes as trophic tracers: combining field sampling and manipulative labelling of food resources for macrobenthos. Mar Ecol Prog Ser 204:79-92

Jack JD, Gilbert JJ (1993) Susceptibility of different-sized ciliates to direct suppression by small and large cladocerans. Freshw Biol 29:19-29

Leakey RJG, Burkill PH, Sleigh MA (1994) Ciliate growth rates from Plymouth Sound: comparison of direct and indirect estimates. J Mar Biol Assoc UK 74:849-861

Lechowicz MJ (1982) The sampling characteristics of electivity indices. Oecologia 52:22-30

Levinsen H, Turner JT, Nielsen TG, Hansen BW (2000) On the trophic coupling between protists and copepods in arctic marine systems. Mar Ecol Prog Ser 204:65-77

Li J, Vincx M (1993) The temporal variation of intertidal nematodes in the Westerschelde. I. The importance of an estuarine gradient. Neth J Aquat Ecol 27:319-326

Li J, Vincx M, Herman PMJ (1996) A model of nematode dynamics in the Westerschelde estuary. Ecol Model 90: $271-284$

Lorenzen S (1974) Die Nematodenfauna der sublittoralen Region der Deutschen Bucht, insbesondere im TitanAbwassergebied bei Helgoland. Veröff Inst Meeresforsch Bremerh 14:305-327

Macek M, Simek K, Pernthaler J, Vyhnalek V, Psenner R (1996) Growth rates of dominant planktonic ciliates in two freshwater bodies of different trophic degree. J Plankton Res 18:463-481

Marchant R, Nicholas WL (1974) An energy budget for the free-living nematode Pelodera (Rhabditidae). Oecologia $16: 237-252$

Middelburg JJ, Barranguet C, Boschker HTS, Herman PMJ, Moens T, Heip CHR (2000) The fate of intertidal microphytobenthos carbon: an in situ ${ }^{13} \mathrm{C}$-labeling study. Limnol Oceanogr 45:1224-1234

Moens T, Vincx M (1997) Observations on the feeding ecology of estuarine nematodes. J Mar Biol Assoc UK 77: 211-227

Moens T, Vincx M (1998) On the cultivation of free-living marine and estuarine nematodes. Helgol Meeresunters 52:115-139

Moens T, Verbeeck L, Vincx M (1999) Feeding biology of a predatory and a facultatively predatory nematode (Enoploides longispiculosus and Adoncholaimus fuscus). Mar Biol 134:585-593

Moens T, Herman P, Verbeeck L, Steyaert M, Vincx M (2000) Predation rates and prey selectivity in two predacious estuarine nematode species. Mar Ecol Prog Ser 205: 185-193

Müller H, Geller W (1993) Maximum growth rates of aquatic ciliated protozoa: the dependence on body size and temperature reconsidered. Arch Hydrobiol 126:315-327

Platt HM, Warwick RM (1983) Free-living marine nematodes. Part I. British enoplids. In: Kermack DM, Barnes RSK (eds) Synopses of the British fauna, Vol 28. Cambridge University Press, Cambridge

Rabette C, Thouvenot A, Lair N (1998) Laboratory experiments on trophic relationships and remote detection between two ciliates and Cyclops vicinus vicinus. Hydrobiologia 373/374:157-167

Rieper M (1985) Some lower food web organisms in the nutrition of marine harpacticoid copepods: an experimental study. Helgol Meeresunters 39:357-366

Rieper M, Flotow C (1981) Feeding experiments with bacteria, ciliates and harpacticoid copepods. Kiel Meeresforsch Sonderh 5:370-375

Sanders RW (1991) Trophic strategies among heterotrophic flagellates. In: Patterson DJ, Larsen J (eds) The biology of 
free-living heterotrophic flagellates. The Systematics Association Spec Vol No 45. Clarendon Press, Oxford, p 21-38 Sanders RW, Porter KG (1990) Bacterivorous flagellates as food resources for the freshwater crustacean zooplankter Daphnia ambigua. Limnol Oceanogr 35:188-191

Schütz L (1966) Ökologische Untersuchungen über die Benthosfauna im Nordostseekanal. II. Autökologie der vagilen und hemisessilen Arten im Bewuchs der Pfähle: Mikround Mesofauna. Int Rev Ges Hydrobiol 51:633-685

Sherr EB, Sherr BF (1994) Bacterivory and herbivory: key roles of phagotrophic protists in pelagic food webs. Microb Ecol 28:223-235

Skoolmun P, Gerlach SA (1971) Jahreszeitliche Fluktuationen der Nematodenfauna im Gezeitenbereich des WeserÄstuars (Deutsche Bucht). Veröff Inst Meeresforsch Bremerh 13:119-138

Smol N, Heip C, Govaert M (1980) The life cycle of Oncholaimus oxyuris (nematoda) in its habitat. Ann Soc R Zool Belg 110:87-103

Soetaert K, Vincx M, Wittoeck J, Tulkens M, Van Gansbeke D (1994) Spatial patterns of Westerschelde meiobenthos. Estuar Coast Shelf Sci 39:367-388

Soetaert K, Vincx M, Wittoeck J, Tulkens M (1995) Meiobenthic distribution and nematode community structure in five European estuaries. Hydrobiologia 311:185-206

Steyaert M, Herman PMJ, Moens T, Widdows J, Vincx M (in press) Tidal migrations of nematodes on an estuarine tidal flat (The Molenplaat, Schelde Estuary, SW Netherlands). Mar Ecol Prog Ser

Editorial responsibility: John Dolan, Villefranche-sur-Mer, France
Stoecker DK, Capuzzo JM (1990) Predation on protozoa: its importance to zooplankton. J Plankton Res 12:891-908

Taylor WD, Johannsson OE (1991) A comparison of estimates of productivity and consumption by zooplankton for planktonic ciliates in Lake Ontario. J Plankton Res 13: 363-372

Tso SF, Taghon GL (1999) Factors affecting predation by Cyclidium sp. and Euplotes sp. on PAH-degrading and nondegrading bacteria. Microb Ecol 37:3-12

Vincx M, Meire P, Heip C (1990) The distribution of nematode communities in the Southern Bight of the North Sea. Cah Biol Mar 31:107-129

von Thun W (1968) Autökologische Untersuchungen an freilebenden Nematoden des Brackwassers. PhD thesis, Kieler Universität, Kiel

Vranken G, Herman PMJ, Vincx M, Heip C (1986) A reevaluation of marine nematode productivity. Hydrobiologia 135:193-196

Walters K, Moriarty DJW (1993) The effects of complex trophic interactions on a marine microbenthic community. Ecology 74:1475-1489

Warwick RM (1971) Nematode associations in the Exe Estuary. J Mar Biol Assoc UK 51:439-454

Wickham S, Gieseke A, Berninger UG (2000) Benthic ciliate identification and enumeration: an improved methodology and its application. Aquat Microb Ecol 22:79-91

Wieser W, Kanwisher J (1960) Growth and metabolism in a marine nematode Enoplus communis Bastian. Z Vergl Physiol 43:29-36

Submitted: June 13, 2001; Accepted: August 29, 2001

Proofs received from author(s): October 16, 2001 